International Journal of Trend in Scientific Research and Development (IJTSRD)

Volume: 3 | Issue: 3 | Mar-Apr 2019 Available Online: www.ijtsrd.com e-ISSN: 2456 - 6470

\title{
Effect of E-Taxation on Revenue Generation in Anambra State
}

\author{
John-Akamelu Chitom R. ${ }^{1}$, Iyidiobi Felicia C. ${ }^{2}$ \\ ${ }^{1}$ Faculty of Management Sciences, Department of Entrepreneur Studies Unit, \\ ${ }^{1}$ Nnamdi Azikiwe University, Awka, Nigeria \\ ${ }^{2}$ Faculty of Management Sciences, Department of Accountancy, \\ 2Enugu State University of Science and Technology, Enugu, Nigeria
}

How to cite this paper: John-Akamelu Chitom R. | Iyidiobi Felicia C. "Effect of E-Taxation on Revenue Generation in Anambra State" Published in International Journal of Trend in Scientific Research and Development (ijtsrd), ISSN: 24566470, Volume-3 | Issue-3, April 2019, pp.1624-1633, URL: https://www.ijtsrd.c om/papers/ijtsrd23 520.pdf

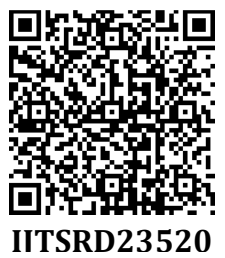

Copyright (C) 2019 by author(s) and International Journal of Trend in Scientific Research and Development Journal. This is an Open Access article distributed under the terms of the Creative Commons

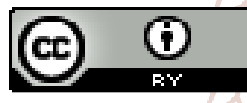
Attribution License (CC BY 4.0) (http://creativecommons.org/license s/by/4.0)

\section{INTRODUCTION}

In the recent times various strata of government in Nigeria are being faced with developmental challenges due to the dwindling and insufficient revenue at its disposal. According to Akpu and Ohaka (2017), the need to strategize toward improving non-oil tax revenue sources which are independent revenue sources available to states and local governments in Nigeria. Akpu and Ohaka (2017) opined that an indispensable tax administrative policy measure for improving tax revenue performance of state government is building a comprehensive and articulated plan of action designed to induce voluntary compliance and effective implementation of tax enforcement program. Tax compliance is behavioral and requires strategies that can induce behavior to succeed. Oyedele, (2016) identified why Nigerians are tax averse which include incoherent fiscal policies, complex and inefficient tax management system, high level of tax leakages, complex tax laws, lack of transparency on utilization of tax revenue and visible development.

The serious decline in price of oil in recent years has led to a decrease in the funds available for distribution to the Federal and State Governments. The need for state and local governments to generate adequate revenue from internal sources has therefore become a matter of extreme urgency and importance (Afuberoh \& Okoye, 2014). This need underscores the eagerness on the part of state and local governments and even the federal government to look for new sources of revenue or to become aggressive and innovative in the mode of collecting revenue from existing sources. Aguolu (2004), states that though taxation may not be the most important source of revenue to the government in terms of the magnitude of revenue derivable from taxation, however, taxation is the most important source of revenue to the government, from the point of view of certainty, and consistency of taxation.

Taxation is a veritable and sustainable source of revenue for government and a tool for fiscal policy and macro-economic management (Nwadialor \& Ekeze, 2015). It is a potential tool of economic and social reform as it pervades all aspect of the economy, individual, companies, citizens and foreigners. The economist sees it as a tool for macroeconomic policy and revenue generation to finance government deficit. It is believe that the magnitude of government surplus or deficit is the major statistical measure of the impact of government fiscal policy on an economy. Azubike (2007) believe that an effective tax system offers the most effective means for mobilizing internal resource and creates an environment conducive for the promotion of economic activity. 
The main objective electronic taxation is to increase the efficiency of tax administrations, specifically by reducing corruption and evasion. However, the second main problem of low revenue generation is political instabilities in developing countries. Similarly, Nkanor and Udu (2016) perceived that electronic internally generated revenue method is a veritable tool for the provision of infrastructural development and for eliminating the vices associated with the manual method, certain problems requiring solutions still exists even with the new regime. In view of this, Maisiba and Atambo (2016) asserted that training is essential for this, because it provides clients with the skills necessary in raising their attitude of voluntarily complying with taxation systems, the designers must ensure that its user friendly.

Afuberoh and Okoye (2014) asserted that revenue derived from taxes has been very low and no physical development actually took place, hence the impact on the poor is not being felt. According to them that inadequate tax personnel, fraudulent activities of tax collectors and lack of understanding of the importance to pay tax by tax payers are some of the problems of this study. The issues mentioned above will therefore constitute the problem to be addressed by this research work.

Various studies had try to investigate the determinants of tax revenues (e.g., Teera (2003); Tanzi and Zee (2000) and Imam and Jacobs (2007)). Imam and Jacobs (2007) explain that real per capita income, share of agriculture in GDP, trade openness, inflation and corruption are the most important determinants of a tax collection. Gupta (2007) finds that several structural factors like per capita GDP, share of agriculture in GDP, trade openness foreign aid, foreign debt and some new institutional variable like corruption and political stability are statistically significant and strong determinants of revenue performance.

Okafor (2012) on Revenue Generation in Nigeria through ETaxation using primary data discovered that electronic taxation will enhance revenue generation in the states studied. Also large data base of the citizenry achieved through proper record keeping will enhance revenue generation. Uremadu and Ndulue, (2011) finds from the field survey profoundly revealed that several factors are responsible for this dismal tax situation such as: high personal income tax rate; complexity of the assessment and collection procedures; lack of adequate tax incentives; lack of taxpayer education and high costs of compliance; among others Adedeji and Oboh, (2012) reveal that tax evasion and avoidance have adversely affected economic growth and development in Nigeria, and also, that lack of good governance is the basis for which tax leakages activities is perpetrated.

Most of the prior studies reviewed were on different aspect of tax system and mainly in foreign countries, though there is limited studies on electronic taxation in relation to the actual tax revenue generated during these periods in Anambra state in particular. It therefore becomes imperative to assess the effect of e-taxation in improving tax revenue generation in Anambra state.

The main objective of this study is to assess the effect of etaxation on revenue generation in Anambra state. Specifically, the study intends to achieve the followings;
1. To examine the effect of e-taxation on tax revenue generation in Anambra state.

2. To determine whether the adoption of e-taxation has reduced tax malpractice in Anambra state.

3. To ascertain the tax revenue improved based on the etaxation adoption in Anambra state.

\section{REVIEW OF RELATED LITERATURE conceptual Framework E-Taxation}

Waweru (2013) stated that electronic tax system is the system that has been developed to replace the current KRA Online system. It is a web-enabled and secure application system that provides a fully-integrated and automated solution for administration of domestic taxes.

According to Atika (2012), electronic tax system forms part of the revenue collection reforms by Kenya Revenue Authority whose main motive is enhancing tax collections and tax efficiency and thus, tax revenues have been increasing rapidly due to the country's rapid economic development accelerated by the new systems In this regard, the planning and formulation phase of an elaborate electronic system strategy was done in the KRA Corporate plan of 2003 and was implemented in the fourth corporate plan of 2009. KRA has a centralized Information Communication Technology (ICT) department that provides support services in terms of electronic systems to the entire organization all these to try and achieve its goals for achieving increased revenue collection and facilitating voluntary compliance by taxpayers (Atika, 2012).

Wasao (2014), describes electronic tax system is an online platform whereby the taxpayer is able to access through internet all the services offered by a financial authority such as the registration for a personal identification number, filing of returns and application for compliance certificate, a perfect example of such system is the Electronic taxation system that was rolled out in 2013 by the Kenya Revenue Authority. Kenya Revenue Authority for instance as one of the financial authorities in the world conducts this Electronic tax system through the Business Process Improvement (BPI) and increases scope of electronic interaction with taxpayers to boost staff productivity and taxpayer service.

The organization realizes preset objectives of efficient and effective operations, collection of accurate, reliable and informative financial reports that comply with relevant legal and regulatory requirements (Maisiba \& Atambo, 2016). Challenges of Electronic Tax Systems are measured in terms of the good that comes with electronic tax system, there are challenges in its implementation, use and maintenance. From the literature review, a good system will need a reliable and accessible internet service and adequate financing to set up the appropriate infrastructure in tax offices (Maisiba \& Atambo, 2016).

\section{Revenue Generation}

The needed revenue generated for such developmental projects, such as construction of good roads, bridges, construction of schools, markets, construction of hospitals, and others are sourced from all form of tax, haulages, fines, fees, royalties and aids from within the states, federal and foreign governments and agencies. Thus, the State Governments cannot draft capital expenditure framework, execute it and adopt comprehensive measures and approach 
to maintaining them without adequate revenue generation (Nkanor \& Udu, 2016).

The term revenue has been defined by various authors in different ways. Adam (2006) in Adesoji and Chike, (2013) defined revenue as the fund required by the government to finance its activities. These funds are generated from different sources such as taxes, borrowing, fine, fees etc. It is also defined as the total amount of income that accrues to an organization (public or private) within a specified period of time (Hamid, 2008). States revenue comprises of receipt from taxation as well as those which are not the proceeds of taxation, but of either the realization from the sale of government properties or other interests and returns from loans and investment earning. Bhatia (2001) contends that revenue receipt include "routine" and "earned" income. For these reasons, according to him, revenue do not include borrowing and recovery of loans from other parties, but it includes tax receipts, donations, grants, fees and fines and so on.

Public revenue according to Stephen and Osagie (1985) is concerned with various ways in which the government raises revenue.

The main administrative measures taken in the past ten years to improve revenue include:

$>$ Accelerated Revenue Generation Programme (ARGP) 1994

$>$ CITI Bank Direct Monitoring and Reporting of Internal Revenue System - 1999

$>$ Electronic Banking System of Revenue Collection and Monitoring (EBS-RCM) - 2000

$>$ Granting Full Autonomy to Lagos Board of Internal Revenue - 2006.

Nightingale (2002) posited that the fund needed for governance in the public sector to finance government activities is referred to as revenue. He added that these funds can be generated from non-oil sources such as income and other forms of tax, royalties, fines, fees, rates and aids from the federal government and foreign financial institutions and countries. Revenue is also described as the cumulative income accruable to an organization (public or private) from one period to another (Ipaye, 2009). Bhatia (2006) contends that revenue receipts include "routine" and "earned" income. For these reasons, according to him, revenue does not include borrowings and recovery of loans and advances previously given to the third tier of government and other associated persons rather, it is comprised of income taxes, vehicle haulages, sales of government unserviceable properties, aids, royalties, rates, fees among others.

Also, Otunbala (2011) affirmed that government revenue involved the entire fund generated from oil and non-oil sources other than fund raised from issue of debt instrument such as government bonds, stocks, treasury certificates and treasury bills from capital and money market. He adds that the non-oil source includes; income tax receipts, charges, royalties, fees, utilities, miscellaneous revenues among others. Stephen and Osagie (1985) stated that public revenue is concerned with the numerous ways in which government raises revenue. From the above definitions, it can be seen that the total amount of cash-inflows accruing to State Government Consolidated Revenue Fund from various oil and nonoil sources within a stipulated time frame constitutes her revenue.

Osisami (1994) opined that revenue that accrues to State Governments in Nigeria is basically categorized into internally generated revenue and external which is collected from the distributable pool.

\section{Effects of Tax Evasion and Avoidance}

Tax evasion and avoidance indubitably have adversely affected government revenue generation and the economy as a whole. However despite the government efforts to curb the practices of tax leakages in Nigeria, the problem of tax evasion and avoidance still persists (Alabi, 2001). There is no doubt that revenue due any government will be reduced by the unpatriotic act of tax evaders. Also, tax avoidance generates investment distortion in the form of the purchase of assets exempted from tax or undervalued for tax purposes. Also, the government will not have sufficient funds in executing its plans and agenda for the nation (Eboziegbe, 2007) since taxation is one of the major sources of government funds and which is being paralyzed by the menace of tax leakages in the form of tax evasion and avoidance. Also, tax evasion is one of the major social problems inhibiting development in developing countries and eroding the existing welfare state in developed economies in the world.

\section{Empirical Studies}

Ouite number of works has been carried out in taxation and its contributions in enhancing revenue generations to boost economic development of the country. In the work of Nkanor and Udu (2016) evaluated the effects of electronic internally generated revenue (e-IGR) on infrastructural development of Ebonyi State. The main objective of the study is to determine the degree of manual and electronic internally generated revenue's impact on infrastructure using capital expenditure as proxy. The dwindling revenue from oil and continued need for public utilities caused the need to empirically determine this relationship. To achieve the main objective of this study, three hypotheses were formulated. Ex-post facto research design was used in this work which involved the use of existing data. Data components of manual and electronic revenue and capital expenditure (infrastructure) of Ebonyi State government between 2011 and 2014 was collected and analyzed using regression and Pearson correlation method with the help of SPSS version 17.0. Results show that the extent of relationship between each independent variable (IGR and e-IGR) were very low on the dependent variable which is Infrastructure development using capital expenditure, but cannot ignore the rate at which their degree changed, signifying an increase in associations. In general, it was discovered that there exist no significant degree of relationship of variables studied.

Maisiba and Atambo (2016) study was guided by the following objectives; to establish the effects of electronic tax payment on revenue collection efficiency by KRA in Uasin Gishu County, to find out the effect of electronic tax filing on revenue collection efficiency of Kenya Revenue Authority in Uasin Gishu County and to establish the challenges facing the use of electronic tax system and give possible recommendations. The study employed a case study research design of KRA Uasin Gishu County. The main data collection tools were questionnaires that were administered to the respondents. The study targeted a population of 102 
respondents who included employees of KRA and tax payers. Data from the field was analyzed using SPSS that included use of descriptive \& inferential statistics. The key findings were that most respondents agreed that KRA has good electronic tax payment System and that for the KRA officials; most of them are conversant with its use and are trained.

Sagas, Nelimalyani and Kimaiyo (2015), did an assessment of the impact of electronic tax register on revenue collection by Kenya Revenue Authority western region, Kenya. Findings from their study indicated that indicated that $75 \%$ of the respondents were of the opinion that ETR machines have helped to curb cases of tax evasion $86 \%$ of the respondents were of the opinion that ETRs have helped increase revenue collection due to their efficient nature.

Ayodeji (2014) looked at the Impact of electronic tax systems on Tax Administration in Nigeria. He argued that the dwindling global fortune occasioned by the fall in the price of crude oil, the major source of wealth for Nigeria shifted the attention of the government and major stakeholders in the country to the revenue generated locally. But the daunting task of boosting the Internally Generated Revenue necessitates the adoption of electronic tax systems technologies to drive Tax administration and concluded that electronic tax systems plays an important role in the increase of internally generated revenue in Nigeria by ensuring compliance thereby boosting productivity and economic activities in the country. It is a change agent for accelerated growth and poverty reduction in Nigeria and the whole of African continent at large. The major recommendation from their study was that necessary laws and regulations have to be passed by the appropriate authorities to reduce or abolish import taxes on information technology hardware such as computers, Servers, printers, biometric scanners and other devices.

Wamathu (2013) studied the effects of electronic taxation on financial performance of audit firms in Kenya. From the finding the study found that there has been timely filing of returns since inception of I-tax, there has been a reduction in audit period due to introduction of I-Tax, respondents were quite knowledgeable. ,system failure when login were less, ITax was user manual friendly , I-tax system was reliable and that I-tax was not user friendly, I-tax system cost effective, Itax system was cost effective and respondent were aware of that I-Tax system was electronic cash register and electronic signature device. She recommended that there is need for the Kenya Revenue Authority to invest on technology in order to reduce the system failure as the study revealed that system failure affects system logins. System failure discourages use of technology.

Muita (2010) in her MBA thesis has also done a related study on the factors that influence adoption and use of e-filing system among Large Taxpayers in Kenya. The study examined the skills required by the users of e-filing, the technology required and the tax authority's preparedness in enhancing the adoption of tax compliance based technology. The study found that for e-filing to effectively take off in Kenya skills, infrastructure and a conducive business environment are needed.

Gekonge and Wallace (2016) investigated the effect of the electronic tax system on revenue collection efficiency of Kenya Revenue Authority at Uasin Gishu County. The study was guided by the following objectives; to establish the effects of electronic tax payment on revenue collection efficiency by KRA in Uasin Gishu County, the study employed a case study research design of KRA Uasin Gishu County. The main data collection tools were questionnaires that were administered to the respondents. The study targeted a population of 102 respondents who included employees of KRA and tax payers. Data from the field was analyzed using SPSS that included use of descriptive \& inferential statistics. The study found that most respondents agreed that KRA has good electronic tax payment System and that for the KRA officials; most of them are conversant with its use and are trained. However, most tax payers indicated difficulty in using the system and blamed lack of computer knowledge, poor internet and unstable power supply as major reasons.

Haroon, Mohammad and Farhan (2015) ascertained the effects of computer information system in the reduction of tax evasion in Jordanians firms. The increased phenomenon of tax evasion recently which is one of the phenomena that limit the performance and effectiveness of the Income Tax Departments in Jordanians firms, and with the tremendous development, technology and scientific progress obviously increased the importance of the development of computer information systems that help in tax evasion reduction. YiShun (2002) determined the factors affecting the adoption of electronic tax-filing systems. Using the technology acceptance model (TAM) as a theoretical framework, this study introduces "perceived credibility" as a new factor that reflects the user's intrinsic belief in the electronic tax-filing systems, and examines the effect of computer self-efficacy on the intention to use an electronic tax-filing system. Based on a sample of 260 users from a telephone interview, the study revealed a strongly support on extended TAM in predicting the intention of users to adopt electronic tax-filing systems. The results also demonstrate the significant effect that computer self-efficacy has on behavioral intention through perceived ease of use, perceived usefulness, and perceived credibility.

Anna and Yusniza (2010) studied the relationship of perceived risk and its facets within the technology acceptance model (TAM) within the tax e-filing context. This paper proposes a conceptual model to further understand the role of perceived risk in influencing consumer behaviour throughout the adoption process. This paper is then developed into concrete research hypotheses for future studies. The model will serve as a useful guideline for strategies development in promoting e-government services, particularly the tax e-filing service.

Sagas, Nelimalyani and Kimaiyo (2015) assessed the impact of electronic tax register on revenue collection by Kenya revenue authority western region, Kenya. Findings from their study indicated that indicated that $75 \%$ of the respondents were of the opinion that ETR machines have helped to curb cases of tax evasion $86 \%$ of the respondents were of the opinion that ETRs have helped increase revenue collection due to their efficient nature.

Ssengonzi (2015) ascertained the impact of electronic tax filing system on tax collection and tax compliance following several claims of lack of transparency, inadequate education on tax matters and corruption in the assessment of taxes. The research employed correlation and cross sectional research designs on a survey population that generally 
included finance officers who handle tax matters in different companies within Mbarara district. These officers were arrived at using the purposive sampling method while the simple random sampling technique was used to select the various companies where the officers work. Data was collected from existing literature and by use of questionnaires. The study found that electronic tax filing system enhanced tax collection and tax compliance.

Akbar, Parviz, Bromand and Payam (2014) delved into the models for adoption of electronic tax returns from the perspective of taxpayers; after explaining the undertaken studies regarding this issue in other countries, the descriptive and inferential analyses of data gathered from the universe under study performed .Thereafter, an examination of the relations existing among the variables of the conceptual model of the study in hand will be undertaken and the research hypotheses will be tested through the agency of adequate statistical patterns. The results demonstrate that the technical-infrastructural variables, social implications, expected efforts, regulatory issues, expected efficiency, access to information and perceived risk hold the highest significance coefficients.

Ramlah (2010) investigated the effective factors affecting citizens' intention to use electronic filing in Malaysia and developed an integrated research model for the implementation of Online taxation through the agency of integration of the Technology Acceptance Model (TAM), diffusion of innovation (DOI), perceived characteristics of innovation (PCI), perceived risk and reliability of the Web, quality of the Web services and the dimensions of political self-efficacy together. A model consisting of 12 factors was examined in this study in which six factors were regarded as the main ones for implementing the electronic government in Malaysia, i.e. in order of importance: anticipated ease of use, anticipated benefits, trust in government, the image of services, quality of services and compliance with services. The study revealed that the government should develop the quality of governmental websites, especially those providing online services to the citizens.

Shih-wu Liang and Hsi-peng Lu (2012) determined the concept of individual self-efficacy and innovative characteristics of the process of online tax return system so as to find out about individuals' stance on adoption of systems provided by the electronic government services. In this paper, the factors affecting taxpayers' intention to adopt an online tax return system at dissimilar stages of the innovation diffusion (IDT) were investigated. A set of factors consists of such items as self-efficacy and personal dimensions of IDT (relative advantage, compatibility, and complexity) and another set consists of such items as social norms and environmental dimensions of IDT. The results demonstrate that the predicted features like testing and visibility capabilities have a significant impact on the adoption intention of the end users.

Schaupp (2010) ascertained the users' intentions in online filing of their taxes through an approved electronic declaration system. This study is Based on the fact that the adoption of electronic tax returns by citizens is significantly influenced by the reputation of the providers of the electronic tax returns which they use for completing and submitting their taxes. Credibility or reputation reduces the predicted risk and increases the predicted probability of use. Therefore, performers should consider factors like security and risk while upgrading their software packages. There are great deals of suppliers of electronic tax returns software's in the U.S.

Anna CheAzmi and Ng Lee (2010) determined the factors which led to the adoption of electronic tax returns among the Malaysian taxpayers using TAM. In this study, a model was used which consisted of three components of usefulness, ease of use, and the risk in which the three factors were predicted. The proposed model in this study is easier when compared to other studies performed on electronic filing. In this research, it revealed that predicted usefulness, predicted ease of use, and predicted risk are important structures for the effect which taxpayers' perceptions have on electronic filing of taxation system. The results also demonstrated that the existence of a suitable and user-friendly system is of great significance for the taxpayers to volunteer to adopt the electronic filing systems of taxation.

Sonja and Mehmet (2014) analyzed the demographic, socioeconomic, and geographic factors affecting electronic tax filing (e-filing) in the United States for the years 1999, and 2004-2007 and the growth in e-filing between 1999 and 2007. Beyond the descriptive analysis, two issues related to electronic tax filing are target of further analysis: First, the variables having a positive impact on e-filing rates and efiling growth are analyzed. Second, because a more detailed look at state and county data indicates high variability within and between states, some demographic, socio-economic, and geographic variables are examined in more detail. This second question addresses the possibility that e-filing - just like other initiatives involving electronic media - could increase the digital gap. They use zip-code level e-filing information and county level demographic, income and unemployment data for each of the years in question. Their findings show a significant variation in e-filing rates across and within states, and rapid growth over time. E-filing rates are found to be lower in rural counties, counties with low population size, counties with a lower share of females, counties with a higher share of Hispanics and Asians, and counties with a higher share of the elderly population.

Mitja, Janez and Maja (2010) Paper presents the use of information communication technology (ICT) in government procedures and its impact on the cost-efficiency of government. The research focuses on investment in ICT to simplify tax procedures in Slovenia. Results show that ICT expenditure is higher than cost savings for tax administration and taxpayers. Nevertheless, several nonfinancial benefits are also important and should be considered.

Santhanamery and Ramayah(2012) ascertained the intention of continuous use of electronic filing System in Malaysia with an emphasis on the role of optimism. Electronic filing, which was introduced in 2006 by the Malaysian government, has become popular over the past five years. However, the implementation of an information system is considered a great success, provided that users go beyond the initial application and continue with its longterm use. The study shows that the number of taxpayers who use the electronic filing, regardless of the predicted risk, is increasing year by year. 
Agusiy (2009) determined the effect of information technology on the efficiency of tax administration in Nigeria, a case Study of Enugu State Board of Internal Revenue. Its main objective is to find out whether the application of Information Technology increases efficiency on tax administration. For the purpose of this study, the researcher adopted the method of survey Research Design. Data used in this research were gotten from both primary and secondary sources including questionnaires and textbooks respectively. These data were analyzed and presented in tables. Three (3) hypotheses were formulated and tested using the Analysis of variance (ANOVA) method. The findings of this research show that effective tax administration resulting from the application of Information Technology leads to an increase in tax base as more potential taxpayers are drawn into the tax net when there is a conducive environment.

Marlon (2001) examined the likely implications of electronic commerce on tax revenues in the Caribbean Community. The study utilized a static microeconomic approach to determine the effects. Based on the assumption that current trends of external trade and growth of electronic commerce in the region will continue, the results will be as follows: tax revenues are likely to increase due to expansion of export markets; tax and tariff revenues will increase due to increase imports of traditional goods and services; tax and tariff revenues will be lost from digitized products; and tax revenues will be lost from the displacement of companies at the intermediate level. The magnitude of these revenue effects will depend on, among other things, import elasticity, competitiveness, and capacity to consistently supply expanding markets.

Much of the related work has been reviewed within and outside the country Nigeria, the study of Okafor (2012) on Revenue Generation in Nigeria through E-Taxation using primary data discovered that electronic taxation will enhance revenue generation in the states studied. Also large data base of the citizenry achieved through proper record keeping will enhance revenue generation. Nkanor and Udu (2016) evaluated the effects of electronic internally generated revenue (e-IGR) on infrastructural development of Ebonyi State.

Gekonge and Wallace (2016) employed a case study research design of KRA Uasin Gishu County and find were that most respondents agreed that KRA has good electronic tax payment System and that for the KRA officials; most of them are conversant with its use and are trained.

Yi-Shun (2002) results strongly support the extended TAM in predicting the intention of users to adopt electronic taxfiling systems. Asianzu and Maiga (2012) found that E-tax adoption rates in developing countries remain low and so its benefits are not fully realized. Sagas, Nelimalyani and Kimaiyo (2015), Findings from their study indicated that indicated that $75 \%$ of the respondents were of the opinion that ETR machines have helped to curb cases of tax evasion $86 \%$ of the respondents were of the opinion that ETRs have helped increase revenue collection due to their efficient nature.

Most of the prior studies reviewed were on different aspect of tax system and mainly in foreign countries, though there is limited study on electronic taxation in relation to the actual tax revenue generated during these periods in Anambra state in particular. It therefore becomes imperative to assess the impact of e-taxation in improving tax revenue generation in Anambra state.

\section{RESEARCH METHODOLOGY \\ Research Design}

This study used descriptive and survey research design. Descriptive statistics are used to describe the basic features of the data in a study while survey design involves the use of sample to obtain the opinion of large number of people. It is a research design that study the information gathered from a fraction or percentage of the population.

The population of the study consists of all the tax officials/administrators of Board Internal Revenue Awka, Anambra state, and data on tax revenue collected from 2008 to 2015. The element of the population includes the Accountants, Auditors and Tax Officers. The total number is 97.

\section{Determination of Sample Size}

A sample size of 78 was obtained from a population of 97 tax officials/administration using Taro Yamane's formula as follows:

This sample size $\mathrm{n}=\ldots+\underline{\mathrm{N}}$

Where

$$
\mathrm{I}+\mathrm{N}(\mathrm{e}) 2
$$

$\mathrm{N}=$ the population size

e= estimated error of $5 \%$

Sample size

Sample size

$$
\begin{aligned}
& =\frac{97}{1+97(0.05)^{2}} \\
& =\frac{97}{1.2425} \\
& =\quad \underline{\mathbf{7 8}}
\end{aligned}
$$

\section{$\underline{78}$}

\section{Method of Data Analysis}

Data collected for the study were analyzed, and one sample t-test was used to test the three hypotheses with aid of SPSS version 20.0 at $5 \%$ level of significance. This will helps in making comparison whether there is a statistical different exist in values after the e-taxation adoption.

\section{Decision Rule:}

Using SPSS, 5\% is considered a normal significance level. The accept reject criterion was based on the computed $t-V$ alue. If the calculated t-value is equal or greater than table t-value, we reject Null and accept alternate hypothesis.

\section{Model Specification}

The equation of this econometric model of this stud is as follows:

$$
\begin{aligned}
& E T A X_{\text {it }}=\mathrm{a}_{0}+\mu_{\mathrm{i}}+\beta_{\mathrm{I}} \mathrm{TAR}_{\mathrm{it}} \\
& E T A X_{\mathrm{it}}=\mathrm{a}_{0}+\mu_{\mathrm{i}}+\beta_{2} \text { RETAMAL }_{\mathrm{it}} \leq \\
& E T A X_{\mathrm{it}}=\mathrm{a}_{0}+\mu_{\mathrm{i}}+\beta_{3} \text { PRE} \text { ETAX }_{\mathrm{it} \geq} \beta_{3 \text { POST }-E T A X}
\end{aligned}
$$

Where:

$E T A X_{i t}$ is Electronic taxation.

$T A R_{i t}=$ is Tax revenue generation.

RETAMAL $L_{i t}=$ is Reduction in tax malpractices.

$\mathrm{a}_{0}=$ slope of the model and $\beta_{\mathrm{I}}, \beta_{2}, \beta_{3}$, coefficient of parameters.

PRE $=$ is before the adoption of E-taxation

POST $=$ is after the adoption of E-taxation 
International Journal of Trend in Scientific Research and Development (IJTSRD) @ www.ijtsrd.com eISSN: 2456-6470

DATA PRESENTATION AND ANALYSIS

Data Distribution and Collection

Out of 78 questionnaires distributed, 70 were completed and returned. This represents $90 \%$.

\section{Data Presentation}

Table 1: Analysis of Data for Research Question One

\begin{tabular}{|c|l|c|c|c|c|c|}
\hline S/N & \multicolumn{1}{|c|}{ SA } & A & UN & D & SD \\
\hline 1 & The new system of taxation improves revenue generation. & 20 & 31 & 2 & 10 & 7 \\
\hline 2 & $\begin{array}{l}\text { Adoption of e-taxation increases the internally generated } \\
\text { revenue of the state. }\end{array}$ & 29 & 34 & 0 & 7 & 0 \\
\hline 3. & $\begin{array}{l}\text { The tax system is easier, quicker and more secured way of } \\
\text { tracking payment made by tax payers from a single view } \\
\text { irrespective of tax being paid for and the mode of payment. }\end{array}$ & 32 & 25 & 4 & 7 & 2 \\
\hline 4. & $\begin{array}{l}\text { Transparency in financial and non-financial reporting is } \\
\text { promoted. }\end{array}$ & 30 & 24 & 3 & 10 & 3 \\
\hline 5 & $\begin{array}{l}\text { Literacy level of e-taxation could greatly affect the efficient } \\
\text { and effective control of tax collection in Nigeria. }\end{array}$ & 27 & 28 & 6 & 9 & 0 \\
\hline
\end{tabular}

Source: Field survey, 2018

Table 2: Analysis of Data for Research Question Two

\begin{tabular}{|c|l|c|c|c|c|c|}
\hline S/N & \multicolumn{1}{|l|}{ SA } & A & UN & D & SD \\
\hline 6 & $\begin{array}{l}\text { With e-taxation it will become difficult for the tax payers to } \\
\text { reduce the amount of tax to be paid. }\end{array}$ & 30 & 24 & 0 & 14 & 2 \\
\hline 7 & $\begin{array}{l}\text { E-taxation system will enable proper assessment of } \\
\text { operations of tax payers to avoid underpayment of tax. }\end{array}$ & 26 & 31 & 3 & 10 & 0 \\
\hline 8 & $\begin{array}{l}\text { Tax can be paid as and when due with the use of e-taxation } \\
\text { hence tax levies can be easily determines. }\end{array}$ & 29 & 21 & 3 & 13 & 4 \\
\hline 9 & $\begin{array}{l}\text { Non availability of Tax Statistics will drastically minimize } \\
\text { and this will leads to conveniences to tax payers. }\end{array}$ & 22 & 28 & 5 & 12 & 3 \\
\hline 10 & $\begin{array}{l}\text { Tax payers can easily process their tax without taken much } \\
\text { of their time hence this will reduce stress on their part. }\end{array}$ & 27 & 34 & 0 & 8 & 1 \\
\hline
\end{tabular}

Source: Field survey, 2018

Table 3: Data on pre and post of E-Taxation in Anambra State

\begin{tabular}{|c|c|}
\hline Years & Taxation in Naira \\
\hline 2008 & $4,671,954,899.32$ (pre of E-Taxation) \\
\hline 2009 & $4,896,888,067.07$ (pre of E-Taxation) \\
\hline 2010 & $5,627,765,980.00$ (pre of E-Taxation) \\
\hline 2011 & 6148922395.00 (pre of E-Taxation) \\
\hline 2012 & 7601585012.15 (post of E-Taxation) \\
\hline 2013 & 8731599912.43 (post of E-Taxation) \\
\hline 2014 & $10,454312316.18$ (post of E-Taxation) \\
\hline 2015 & $14,793120188.67$ (post of E-Taxation) \\
\hline
\end{tabular}

Source: BIR, Onitsha

Test of Hypotheses (Null)

Hypothesis One

Ho: E-taxation has no effect on tax revenue generation in Anambra state.

One-Sample Statistics

\begin{tabular}{|c|c|c|c|}
\hline $\mathbf{N}$ & Mean & Std. Deviation & Std. Error Mean \\
\hline 5 & 14.00 & 11.554 & 5.167 \\
\hline 5 & 14.00 & 16.325 & 7.301 \\
\hline 5 & 14.00 & 13.583 & 6.075 \\
\hline 5 & 14.00 & 12.390 & 5.541 \\
\hline 5 & 14.00 & 12.748 & 5.701 \\
\hline
\end{tabular}

One-Sample Test

\begin{tabular}{|c|c|c|c|c|c|}
\hline \multicolumn{6}{|c|}{ Test Value $=0$} \\
\hline \multirow{2}{*}{$\mathbf{t}$} & \multirow{2}{*}{ df } & \multirow{2}{*}{ Sig. (2-tailed) } & \multirow{2}{*}{ Mean Difference } & \multicolumn{2}{|c|}{$95 \%$ Confidence Interval of the Difference } \\
\hline & & & & Lower & Upper \\
\hline 2.709 & 4 & .054 & 14.000 & -.35 & 28.35 \\
\hline 1.918 & 4 & .128 & 14.000 & -6.27 & 34.27 \\
\hline 2.305 & 4 & .083 & 14.000 & -2.87 & 30.87 \\
\hline 2.527 & 4 & .065 & 14.000 & -1.38 & 29.38 \\
\hline 2.456 & 4 & .070 & 14.000 & -1.83 & 29.83 \\
\hline
\end{tabular}


Decision: If t-value is equal or greater than "Sig" value there is significant effect, we reject Null and accept alternate hypothesis. However, looking at the result, all the responses show positive results; the t-value has up to 11.915 as against sig value of .886 in all the questions raised. This indicates that the electronic system of taxation is better in revenue generation of the state. We therefore reject null hypothesis and accept alternative hypothesis which state that e-taxation has effect on tax revenue generation in Anambra state

\section{Hypothesis Two}

Ho: Adoption of e-taxation has not reduced tax malpractice in Anambra state.

One-Sample Statistics

\begin{tabular}{|c|c|c|c|}
\hline $\mathbf{N}$ & Mean & Std. Deviation & Std. Error Mean \\
\hline 5 & 14.00 & 13.191 & 5.899 \\
\hline 5 & 14.00 & 13.838 & 6.189 \\
\hline 5 & 14.00 & 11.136 & 4.980 \\
\hline 5 & 14.00 & 10.794 & 4.827 \\
\hline 5 & 14.00 & 15.572 & 6.964 \\
\hline
\end{tabular}

\begin{tabular}{|c|c|c|c|c|c|}
\hline \multicolumn{7}{|c|}{ One-Sample Test } \\
\hline \multirow{2}{*}{$\mathrm{t}$} & \multirow{2}{*}{$\mathrm{df}$} & \multirow{2}{*}{ Sig. (2-tailed) } & Mean Difference & 95\% Confidence Interval of the Difference \\
\cline { 5 - 7 } & & & & Lower & Upper \\
\hline 2.373 & 4 & .077 & 14.000 & -2.38 & 30.38 \\
\hline 2.262 & 4 & .086 & 14.000 & -3.18 & 31.18 \\
\hline 2.811 & 4 & .048 & 14.000 & .17 & 27.83 \\
\hline 2.900 & 4 & .044 & 14.000 & .60 & 27.40 \\
\hline 2.010 & 4 & .115 & 14.000 & -5.34 & 33.34 \\
\hline
\end{tabular}

Decision: If t-value is equal or greater than "Sig" value there is significant effect, we reject Null and accept alternate hypothesis. However, looking at the result, all the responses show positive results; the t-value has up to 12.356 as against sig value of 370 in all the questions raised. This indicates that the adoption of electronic taxation is a welcome development in revenue generation of the state. We therefore reject null hypothesis and accept alternative hypothesis which state that adoption of etaxation has not reduced tax malpractice in Anambra state

\section{Hypothesis Three}

Ho: Tax revenue has not improved based on the adoption of e-taxation in Anambra state.

\section{One-Sample Statistics}

\begin{tabular}{|c|c|c|c|c|}
\hline & N & Mean & Std. Deviation & Std. Error Mean \\
\hline PREETAX & 4 & 5322011167.3300 & 655439535.52429 & 327719767.76214 \\
\hline POSTETAX & 4 & 7526793502.8075 & 660635909.77040 & 330317954.88520 \\
\hline
\end{tabular}

\begin{tabular}{|c|c|c|c|c|c|c|}
\hline & \multicolumn{9}{|c|}{ One-Sample Test } \\
\cline { 2 - 7 } & $\mathbf{t}$ & $\mathrm{dff}$ & Sig. (2-tailed) & Mean Difference & 95\% Confidence Interval of the Difference \\
\cline { 5 - 8 } & & & .001 & 5322011167.3300 & 4279060603.2470 & 6364961731.4130 \\
\hline PREETAX & 16.240 & 3 & .000 & 7526793502.8075 & 6475574347.7143 & 8578012657.9007 \\
\hline POSTETAX & 22.787 & 3 & &
\end{tabular}

\section{Decision:}

From the above table, the mean of tax revenue for the pre etaxation is 5322011167.33 as against the mean post etaxation which is 7526793502.81 . In this case the mean of pre e-taxation is lower than that of post e-taxation. Looking at the Confidence Interval of the Difference, pre e-taxation has lower case of 4279060603.25 and upper case of 6364961731.41 while post e-taxation has lower case of 6475574347.714 and upper case of 8578012657.90. This showed that the adoption of e-taxation has improvement on tax revenue of the State. Based on this, the study rejects null hypothesis and accept the alternative hypothesis which state that tax revenue has not improved based on the adoption of e-taxation in Anambra state.

\section{Discussion of Findings}

The analysis of the data in relation to the electronic taxation in Anambra state, the study revealed that E-taxation has effect on tax revenue generation in Anambra state. also that the adoption of e-taxation has reduced tax malpractice in Anambra state while the secondary data shows that tax revenue has improved based on the adoption of e-taxation in Anambra state.

This result is in line with that of Okafor (2012) discovered that electronic taxation will enhance revenue generation in the states studied. Sagas, Nelimalyani and Kimaiyo (2015) revealed from their study indicated that indicated that 75\% of the respondents were of the opinion that ETR machines have helped to curb cases of tax evasion $86 \%$ of the respondents were of the opinion that ETRs have helped increase revenue collection due to their efficient nature. Ssengonzi (2015) found that E-Tax system generally has improved tax administration in areas where it is applied; however the research has shown that there are still challenges faced in applying it, like power interruptions, poor internet connectivity, etc. Also, Lerche, Kiefer and Lucante (2011) concluded that Computerization of tax and revenue authorities can contribute to reaching the goal of good (financial) governance. Ayodeji (2014) concluded that electronic tax systems plays an important role in the increase of internally generated revenue in Nigeria by 
ensuring compliance thereby boosting productivity and economic activities in the country.

\section{CONCLUSIONS AND RECOMMENDATIONS Conclusion}

This study investigated the effect of electronic taxation on revenue from 2008 to 2015. The result of the analysis revealed that tax revenue base has buoyancy above unity with e-taxation as the most buoyant tax revenue generation. This support the thinking that it will constitute a major source of revenue generation in both short and long run to meet government spending requirement.

However, E-Tax system generally has improved tax administration in areas where it is applied; however the research has shown that there are still challenges faced in applying it, like power interruptions, poor internet connectivity, and lack of internet access in office premises for some businesses.

Based on the findings from the study, the researcher made the following suggestions;

1. Governments has it as a duty to established wellequipped database on tax payers with the aim of identifying all possible sources of income of tax payers for tax purpose.

2. Tax officials must be adequately trained, well equipped and well-motivated to carry out their jobs effectively using the new electronic means of paying tax.

\section{References}

[1] Afuberoh, D. \& Okoye, E., (2014). The impact of taxation on revenue generation in Nigeria: A study of federal capital territory and selected states. International journal of public administration and management research (IJPAMR), 2(2) ISSN: 2350-2231 (Online) ISSN: 2346-7215 (Print)

[2] Adedeji, T. 0. \& Oboh, C. S. (2012). An empirical analysis of tax leakages and economic growth in Nigeria" European journal of economics, finance and administrative sciences ISSN 1450-2275 Issue 48 (2012) (C) EuroJournals, Inc. 2012 http://www.eurojournals.com/EJEFAS.htm.

[3] Akpu, U. G. \& Ohaka, J. (2017). Tax compliance strategy and tax revenue yield: empirical evidence from Rivers State, Nigeria (2007-2016). Pyrex Journal of Taxation and Accounting Management. Vol 1 (2) pp. 9-23.

[4] Alabi, S. (2001). Tax planning" a paper delivered at the workshop on Nigerian corporate and personal income tax management, Yaba, Lagos, August 15th.

[5] Alm, J. \& Martinez-Vazquez, J. (2001). Societal institutions and tax evasion in developing and transition countries". A paper prepared for a public finance in developing and transitional countries conference; Georgia State University.

[6] Anna, A. C. \& Yusniza, K. (2010). Adoption of tax efiling: A conceptual paper. African Journal of Business Management 4(5), pp. 599-603, May 2010 Available online at http://www.academicjournals.org/AJBM

[7] Agusiy, B. A. (2009). Effects of information technology on the efficiency of tax administration in Enugu Nigeria. department of accountancy faculty of management and social science caritas university Amorji-Nike Enugu, Enugu state.
[8] Akbar, B., Parviz M., Bromand, A. \& Payam, A. (2014). A study of the models for adoption of e-tax returns from the perspective of taxpayers. Indian Journal of Fundamental and Applied Life SciencesISSN: 2231- 6345 (Online) An Open Access, Online International Journal Available at http://http://www.cibtech.org/sp.ed/jls/2014/01/jls.ht m 2014 Vol. 4

[9] Asianzu, E. \& Maiga, G. (2012). A Consumer Based Model for Adoption of E-Tax Services in Uganda. ISTAfrica 2012 Conference Proceedings Paul Cunningham and Miriam Cunningham (Eds) IIMC International Information Management Corporation, 2012 ISBN: 9781-905824-34-2 Copyright (C) 2012 The authors www.IST-Africa.org/Conference2012 Page 1 of 15.

[10] Ayua, I. A. (1999). The Nigerian tax law. Ibadan: spectrum law publishing.

[11] Azubike, 0. (2007). Tax and economic growth in Nigeria Time series analysis.

[12] Aguolu, 0. (2004). Taxation and Tax Management in Nigeria, 3rd Edition, Enugu; Meridan Associates.

[13] Bird, R. M. \& Zolt, E. M. (2008). Technology and taxation in developing countries: from hand to mouse" UCLA law review 52 No. 6 (2008):1627-95.

[14] Brondolo, J. Silvani, C. Borgne, E. \& Bosch, F. (2008). Tax administration reform and fiscal adjustment": the case of Indonesia (2001-07) IMF working paper No. 08/129.

[15] Bhatia, H. L. (2006). Public finance vikex pub House PVTLTD DEHL.

[16] Eboziegbe, M.O. (2007). Tax evasion hinders local governments", the Saturday tribune, October: 13.

[17] FIRS (2009). Gauge: A quarterly publication of the federal Inland Revenue service, April-June.

[18] Gekonge, J. M. \& Wallace, A. (2016). Effects of electronic- tax system on the revenue collection efficiency of Kenya Revenue Authority: A Case of Uasin Gishu County. Imperial Journal of Interdisciplinary Research (IJIR) 2(4), 2016 ISSN: 2454-1362, http://www.onlinejournal.in Imperial Journal of Interdisciplinary Research (IJIR) Page 815

[19] Gupta, S.A (2007). Determinants of tax revenue efforts in developing countries" IMF working paper No.07/184 Washington, DC: the international monetary fund.

[20] Haroon, A., Mohammad, A. \& Farhan, A. (2015). The impact of computer information systems in the reduction of the tax evasion / exploratory study in Jordanians firms. journal of theoretical and applied information Technology 78(1) ISSN: 1992-8645 www.jatit.org E-ISSN: 1817-3195

[21] Imam, P. A. \& Jacobs, D. F. (2007). Effect of corruption on tax revenues in the middle east" IMF Working Paper No.07/270. IMF institute and fiscal affairs department.

[22] Ipaye, A. R. (2009). Taxpayers' money in action: the worth of my tax as a tool for economic, social and infrastructural development - Lagos state as a case study", Association of National Accountants of Nigeria, commemorative lecture

[23] Rotimi, O., Udu, U.a.A. \& Abdul-Azeez (2013) Revenue generation and engagement of tax consultants in Lagos State, Nigeria. Continuous tax Evasion and 
Irregularities. European Journal of Business and Social Science, Vol. 1 No. 10, pp 25-35.

[24] Jackson, B. R. \& Milliron, V. C. (1986). Tax compliance research: findings, problems and prospects. Journal of accounting literature, 5, pp. 125-165.

[25] Jen-Ruei F., Cheng-Kiang F. \& Wen-Pin C. (2006). Acceptance of electronic tax filing: a study of taxpayer intentions. Information \& Management 43 (2006) 109126.

[26] Kiabel, B.D. \& Nwokah, N.G. (2009). Curbing tax evasion and avoidance in personal income tax administration: A study of the south-south states of Nigeria. European J. Econs. Fin. Admin. Sci., 15: 16-61.

[27] Karimi, H., Maina, K. E., \& Kinyua, J. M. (2017). Effect of technology and information systems on revenue collection by the county government of Embu, Kenya. International Academic Journal of Procurement and Supply Chain Management.1,(I5), 1-26.

[28] Mugambi, F. K. \& Wanjohi, J. M. (2017). factors affecting implementation of revenue collection systems in county governments in Kenya, a case of Meru county. IJRDO - Journal of Social Science and Humanities Research.3(8) ISSN: 2456-2971

[29] Muriithi, M.K. (2003). Tax reforms and financial mobilization in Kenya.

[30] Mitja D., Janez, S. \& Maja, K.L. (2010). E-government and cost-effectiveness: e-taxation in Slovenia Transylvanian Review of Administrative Sciences, No. 31E/2010 pp. 48-57

[31] Marlon, A. B. (2001). The impact of electronic commerce on tax revenues in the Caribbean Community. Regional Tax Policy and Administration Unit CARICOM, Georgetown Guyana, SA.

[32] Maisiba, G. J., \& Atambo, W. (2016). Effects of electronic-tax system on the revenue collection efficiency of kenya revenue authority: A case of Uasin Gishu County. Imperial Journal of Interdisciplinary Research, 2(4).

[33] Nightingale, K. (2002). Taxation theory and practices, 4th ed. England pearson education Ltd.

[34] Nwadialo, R. E. \& Ekeze, A. C. (2015). Productivity of the Nigerian Tax System (1994 - 2013) http://ijba.sciedupress.com International Journal of Business Administration 6(4).

[35] Nwachukwu, I. (2006). Institutions indulge in tax evasion despite huge profits they make in Nigeria" The Tribune. September: 1.

[36] Odusola, A. F. (2003). Internally generated revenue at the local government: issues and challenges.' paper presented at the workshop on revenue generation at the state government level, October. Ibadan: University of Ibadan.

[37] Okafor, G. T. (2012). Revenue generation in Nigeria through e-taxation. European Journal of economics, finance and administrative sciences ISSN 1450-2275 Issue 49 (2012) (C) EuroJournals, Inc. 2012 http://www.eurojournals.com/EJEFAS.htm.।

[38] Olaoye, C. O., (2008). Concepts of Taxation Nigeria. Clement Publishing, Ijagbo/Ofa, Kwara State.

[39] Oyedele, T. (2016) Guess how many Nigerians pay tax and how our government spends the money: - PWC Nigeria.
[40] Ojo, S. A. (2003). Principles of Nigeria Tax. Ilorin: Sagribra Publishing House; 70.

[41] Olatundun, J. A. (2008). Tax, investment and q: evidence from firm and industry level data in Nigeria" International Research Journal of Finance and Economics ISSN 1450-2887 Issue 16 (2008) (C) EuroJournals Publishing, Inc. 2008 http://www.eurojournals.com/finance.htm.

[42] Orewa, G.O. (1957). Taxation in western Nigeria. London: Oxford University Press.

[43] Otubala, 0. A. (2011). Effect of public revenues on economic growth in nigeria (1980-2008). An Unpublished thesis of Ahmadu Bello University, Zaria in Partial Fulfillment of the Requirements for the Award of Masters of Science Degree In Economics.

[44] Sikka, P. \& Hampton, M. P. (2005). The role of accountancy firms in tax avoidance: some evidence and issues", Accounting Forum, 29(3), pp. 325-343.

[45] Soyode, L., \& Kajola, S.O. (2006). Taxation: principles and practice in Nigeria (1st Ed.). Ibadan: Silicon.

[46] Santhanamery, T. \& Ramayah, T. (2012). Continued usage intention of e-filing system in Malaysia: The Role of Optimism Bias." 1877-0428 (C) 2012 The Authors. Published by Elsevier Ltd. Available online at www.sciencedirect.com, Procedia-Social and Behavioral Sciences 65 (2012) 397-403.

[47] Saha, P., Nath, A. K., \& Salehi-Sangari, E., (2012). Evaluation of government e-tax websites: an information quality and system quality approach." Transforming Government: People, Process and Policy Vol. 6 No. 3, 2012 pp. 300-321.

[48] Sonja, E. P. \& Mehmet, S. T. (2014). Electronic Tax Filing in the United States: An Analysis of Possible Success factors. Electronic Journal of e-Government Volume 12 Issue 1 2014, (pp22-38), available online at www.ejeg.com.

[49] Teera, J. M. (2003). Could do better: an appraisal of Uganda's tax performance relative to Sub Saharan Africa," working paper University of Bath:

[50] Tanzi, V.\& Zee, H. (2000). Tax policy for emerging markets: developing countries." IMF Working Paper WP/00/35. Washington DC: International Monetary Fund.

[51] Toby, R. (1983). The Theory and Practice of Income Tax, Macmillan Press Ltd.

[52] Uadiale, O. M., T.O. Fagbemi \& J.O. Ogunleye (2010). An empirical study of the relationship between culture and personal income tax evasion in Nigeria. European Journal of Economics, Finance and Administrative Sciences, 20, 116-126.

[53] Uremadu, S. O. \& Ndulue, J. C. (2011). A review of private sector tax revenue generation at local government level: evidence from Nigeria" Journal of public administration and policy research 3(6), pp. 174183, June 2011 Available online http://www.academicjournals.org/jpapr ISSN 21412480 (C2011 Academic Journals Review.

[54] Yi-Shun, W. (2002). The adoption of electronic tax filing systems: an empirical study. Government Information Quarterly 20 (2002) 333-352 